\title{
Head and Neck Cancer TNM Finding v7
}

National Cancer Institute

\section{Source}

National Cancer Institute. Head and Neck Cancer TNM Finding v7. NCI Thesaurus. Code C88937.

A finding about one or more characteristics of head and neck cancer, following the rules of the TNM AJCC V7 classification system. 